\title{
1 Bacteremia and Blood Culture Utilization During COVID-19 Surge in New York City
}

3 Jorge Sepulveda, MD, $\mathrm{PhD}^{1}$, Lars F. Westblade, $\mathrm{PhD}^{2,3}$, Susan Whittier, $\mathrm{PhD}^{1}$, Michael J. Satlin, $\mathrm{MD}^{3}$,

4 William G. Greendyke, $\mathrm{MD}^{4}$, Justin G. Aaron, $\mathrm{MD}^{4}$, Jason Zucker, MD ${ }^{4}$, Donald Dietz, $\mathrm{MD}^{4}$, Magdalena

5 Sobieszczyk, MD ${ }^{4}$, Justin J. Choi, MD³ ${ }^{3}$ Dakai Liu, $\mathrm{PhD}^{5}$, Kelvin Espinal, BA ${ }^{6}$, Sarah Russell, BA ${ }^{6}$,

6 Dennis Camp, BA ${ }^{6}$, Charles Connelly, $\mathrm{BS}^{6}$, Daniel A. Green, $\mathrm{MD}^{1, \#}$

7

$8 \quad{ }^{1}$ Department of Pathology \& Cell Biology, Columbia University Irving Medical Center, New York, NY

$9 \quad{ }^{2}$ Department of Pathology and Laboratory Medicine, Weill Cornell Medicine, New York, NY

$10{ }^{3}$ Division of Infectious Diseases, Department of Internal Medicine, Weill Cornell Medicine, New York,

$11 \mathrm{NY}$

$12{ }^{4}$ Division of Infectious Diseases, Department of Internal Medicine, Columbia University Irving Medical

13 Center, New York, NY

$14{ }^{5}$ Department of Pathology and Clinical Laboratories, NewYork-Presbyterian Queens Hospital

$15{ }^{6}$ Clinical Laboratories, NewYork-Presbyterian Hospital, New York, NY

17 Keywords: COVID-19, SARS-CoV-2, Bacteremia, Sepsis, Blood Culture

18 Running Title: Blood Culture COVID-19

20 \#Address correspondence to:

21 Daniel A. Green, M.D.

223959 Broadway

23 Microbiology, CHONY C-324

24 New York, NY 10032

25 (212)-305-6301

26 dag2149@cumc.columbia.edu

NOTE: This preprint reports new research that has not been certified by peer review and should not be used to guide clinical practice. 1 
medRxiv preprint doi: https://doi.org/10.1101/2020.05.05.20080044; this version posted May 6, 2020. The copyright holder for this preprint (which was not certified by peer review) is the author/funder, who has granted medRxiv a license to display the preprint in perpetuity.

It is made available under a CC-BY-NC 4.0 International license .

\section{Abstract:}

28 A surge of patients with coronavirus disease 2019 (COVID-19) presenting to New York City hospitals in

29 March 2020 led to a sharp increase in the utilization of blood cultures, which overwhelmed the capacity

30 of automated blood culture instruments. We sought to evaluate the utilization and diagnostic yield of

31 blood cultures during the COVID-19 pandemic to determine prevalence and common etiologies of

32 bacteremia, and to inform a diagnostic approach to relieve blood culture overutilization. We performed a

33 retrospective cohort analysis of 88,201 blood cultures from 28,011 patients at a multicenter network of

34 hospitals within New York City to evaluate order volume, positivity rate, time to positivity, and etiologies

35 of positive cultures in COVID-19. Ordering volume increased by 34.8\% in the second half of March 2020

36 compared to the first half of the month. The rate of bacteremia was significantly lower among COVID-19

37 patients (3.8\%) than COVID-19 negative patients (8.0\%) and those not tested (7.1\%), p $<0.001$.

38 COVID-19 patients had a high proportion of organisms reflective of commensal skin microbiota,

39 reducing the bacteremia rate to $1.6 \%$ when excluded. More than $98 \%$ of all positive cultures were

40 detected within 4 days of incubation. Bloodstream infections are very rare for COVID-19 patients, which

41 supports the judicious use of blood cultures in the absence of compelling evidence for bacterial co-

42 infection. Clear communication with ordering providers is necessary to prevent overutilization of blood

43 cultures during COVID-19 surges, and laboratories should consider shortening the incubation period from

445 days to 4 days to free additional capacity.

45

46

47

48

49

50

51

52 
medRxiv preprint doi: https://doi.org/10.1101/2020.05.05.20080044; this version posted May 6, 2020. The copyright holder for this preprint (which was not certified by peer review) is the author/funder, who has granted medRxiv a license to display the preprint in perpetuity.

It is made available under a CC-BY-NC 4.0 International license .

\section{Introduction:}

The rapid spread of severe acute respiratory syndrome coronavirus 2 (SARS-CoV-2) across New

56 York City in March 2020 led to an unprecedented strain on hospital resources, including shortages of

57 beds, ventilators, personal protective equipment, and diagnostic materials such as laboratory reagents and

58 nasopharyngeal swabs ${ }^{1-3}$. The surge of febrile patients to our network of hospitals in New York City led

59 to a sudden and dramatic increase in the number of blood cultures received in our laboratories, which

60 overwhelmed the capacity of our automated blood culture instruments.

61 While blood cultures are an essential tool for the diagnosis and management of bloodstream

62 infections among patients presenting to the emergency department and among inpatients, data are lacking

63 on their utility for patients with suspected or confirmed coronavirus disease 19 (COVID-19). While many

64 patients with severe COVID-19 are treated with empiric antibiotics for potential bacterial co-infections,

65 the rate of bacteremia among these patients is unknown, and the benefit of empiric antibiotic therapy is

unproven. Frequent ordering of blood cultures for patients with COVID-19 may overwhelm a laboratory's

67 capacity to perform and result these tests, which may negatively impact the overall benefit of testing for

68 the entire medical center. Therefore, we sought to evaluate both the utilization and diagnostic yield of

69 blood cultures during a surge of COVID-19 patients presenting to our hospitals, including positivity rates

70 for patients with and without COVID-19, as well as the most common causes of bacteremia among

71 COVID-19 patients. We also relay strategies for diagnostic stewardship to mitigate challenges that may

72 arise from a surge of blood culture orders.

73

\section{Methods:}

75

76 Study Design: 
medRxiv preprint doi: https://doi.org/10.1101/2020.05.05.20080044; this version posted May 6, 2020. The copyright holder for this preprint (which was not certified by peer review) is the author/funder, who has granted medRxiv a license to display the preprint in perpetuity.

It is made available under a CC-BY-NC 4.0 International license .

A retrospective cohort study was conducted on patients with blood cultures performed at

79 NewYork-Presbyterian Hospitals located throughout New York City from January 1, 2020 to March 31,

80 2020. Corresponding data from January 1, 2019 to March 31, 2019 were collected to establish a seasonal

81 historic baseline of blood culture ordering and positivity. Records were extracted from the laboratory

82 information system (Cerner Millennium, Cerner, North Kansas City, MO) using a Cerner Command

83 Language query and included information on performing facility, SARS-CoV-2 reverse transcription-

84 polymerase chain reaction (RT-PCR) result, blood culture result, organism(s) identified, and blood culture

85 collection date and time. After the study period concluded, the blood culture incubation period was

86 reduced from 5 days to 4 days to free additional space on the instruments. In a subset of patients for

87 whom data were available, the interval from time of blood culture collection to time of Gram stain was

88 used to calculate the time to blood culture positivity during the study period, which was used to examine

89 the predicted effect of this intervention.

90

Laboratory Methods:

Blood cultures were incubated on BACTEC FX (Becton, Dickinson and Co., Franklin Lakes, NJ)

94 or VersaTrek (Thermo Fisher Scientific, Inc., Waltham, MA) instruments for a maximum of 5 days.

95 SARS-CoV-2 RT-PCR testing was performed in-house with the following assays: cobas SARS-CoV-2

96 (Roche Molecular Systems, Inc., Branchburg, NJ), Xpert Xpress SARS-CoV-2 (Cepheid, Sunnyvale,

97 CA), RealStar SARS-CoV-2 (Altona Diagnostics USA, Inc., Plain City, OH), and a laboratory-developed

98 test developed by the Wadsworth Center at the New York State Department of Health.

Participants:

A total of 88,201 blood cultures from 28,011 patients were included from the following hospitals

103 within the NewYork-Presbyterian network: Columbia University Irving Medical Center (32,788), Weill- 
medRxiv preprint doi: https://doi.org/10.1101/2020.05.05.20080044; this version posted May 6, 2020. The copyright holder for this preprint (which was not certified by peer review) is the author/funder, who has granted medRxiv a license to display the preprint in perpetuity.

It is made available under a CC-BY-NC 4.0 International license .

104 Cornell Medical Center (26,794), Allen Hospital (6,053), Queens Hospital (16,913), and Lower

105 Manhattan Hospital (5,653). Patients were stratified by SARS-CoV-2 RT-PCR result as positive,

106 negative, or not tested. For the purposes of classifying blood cultures by SARS-CoV-2 RT-PCR status,

107 we used the following criteria:

108

109

1. Blood cultures were labeled as SARS-CoV-2 status "Positive" if the blood culture was performed within 2 days of a positive SARS-CoV-2 RT-PCR result and for all subsequent blood cultures after a positive SARS-CoV-2 RT-PCR result. performed within 2 days of a negative SARS-CoV-2 RT-PCR result and for all subsequent blood cultures, unless the patient had a subsequent positive SARS-CoV-2 RT-PCR result, for which the

121 This study was approved by the Institutional Review Boards of Columbia University Irving Medical 122 Center and Weill-Cornell Medicine. status was changed to "Positive" for any blood cultures performed within 2 days of the positive SARS-CoV-2 RT-PCR result.

3. All other blood cultures were labeled as SARS-CoV-2 status "Not tested."

The 2-day interval was used to account for turnaround time from test ordering to SARS-CoV-2 test results, as blood culture and SARS-CoV-2 RT-PCR tests ordered on the same day may have taken up to 2 days for the SARS-CoV-2 RT-PCR result to become available.

Data Analysis:

\section{6 (2020). R: A language and environment for statistical computing. R Foundation for Statistical}

127 Computing, Vienna, Austria. URL https://www.R-project.org). Blood culture volumes and positivity rates

128 were calculated and graphed by day, with a moving regression line estimated by the default geom_smooth

129 function of the ggplot2 R package version 3.3.0, namely locally estimated scatterplot smoothing (LOESS) 
medRxiv preprint doi: https://doi.org/10.1101/2020.05.05.20080044; this version posted May 6, 2020. The copyright holder for this preprint (which was not certified by peer review) is the author/funder, who has granted medRxiv a license to display the preprint in perpetuity.

It is made available under a CC-BY-NC 4.0 International license .

for data with less than 1000 points and generalized additive model (GAM) for data with more than 1000

131 points. The regression lines were overlayed in the scatterplot to analyze directional trends.

Volumes and positivity rates were also stratified by SARS-CoV-2 RT-PCR result using the rules

133 specified above, and by various patient categories. Bacterial and fungal etiologies of blood cultures were

134 also collected and stratified by SARS-CoV-2 RT-PCR result. Differences in continuous data between

135 groups were assessed by one-way analysis of variation (ANOVA), whereas categorical data were

136 analyzed by Pearson's chi-squared analysis. Categorical data were graphed by the assoc function of the

$137 v c d$ R package (version 1.4.7) and colored according to Pearson's residuals to demonstrate sources of

138 difference between observed and expected proportions in different groups.

$\underline{\text { Results: }}$

Blood Culture Volumes and Positivity Rate:

During the study period, blood culture volumes rose substantially during the month of March

2020 (Figure 1). Overall, 8,784 blood cultures were performed during the second half of March 2020, representing a $34.8 \%$ increase from the first half of the month. Patients who were positive for SARS-

147 CoV-2 accounted for the majority of the increased blood culture ordering. Notably, the increased ordering

148 among COVID-19 patients was not primarily attributable to repeated ordering, as 48.2\% of COVID-19

149 patients had more than 2 blood culture sets drawn, compared to $66.2 \%$ of COVID-19 negative patients

150 and $62.1 \%$ of patients not tested for SARS-CoV-2 $(p<0.001$, Supplemental Tables 1 and 2$)$

The blood culture positivity rate was significantly lower for patients that tested positive for

152 SARS-CoV-2 (3.8\%) than for patients that tested negative for SARS-CoV-2 (8.0\%) or for patients that

153 were not tested $(7.1 \%, \mathrm{p}<0.001$, Table 1). As additional COVID-19 patients presented to the hospital

154 throughout the month of March 2020, the overall rate of blood culture positivity continued to decrease

155 further (Figure 2). 
medRxiv preprint doi: https://doi.org/10.1101/2020.05.05.20080044; this version posted May 6, 2020. The copyright holder for this preprint (which was not certified by peer review) is the author/funder, who has granted medRxiv a license to display the preprint in perpetuity. It is made available under a CC-BY-NC 4.0 International license .

Etiologies of Bacteremia:

Among patients with positive blood cultures, COVID-19 patients had a significantly higher proportion of cultures that likely represented contamination with normal skin microbiota than all other

161 groups (Figure 3 and Table 2). Organisms were labeled as likely contaminants if they were isolated only 162 once per patient and belonged to groups generally defined as commensal skin microbiota. ${ }^{4}$ Coagulase163 negative Staphylococcus species accounted for 59.7\% of all positive cultures among COVID-19 patients, 164 compared to $32.0 \%$ among patients that tested negative for SARS-CoV-2, and $29.8 \%$ among patients that 165 were not tested for SARS-CoV-2 in 2020 (p < 0.001). Corynebacterium species, Bacillus species, and 166 Micrococcus species were also seen more frequently among COVID-19 patients (Supplemental Table

167 3). When potential contaminants were excluded, the rate of bacteremia for COVID-19 patients decreased 168 to $1.6 \%$, which was significantly lower than the rate of bacteremia excluding contaminants among 169 COVID-19 negative patients (5.9\%) and during the same period in $2019(5.7 \%, \mathrm{p}<0.001$, Table 3). The 170 most common causes of true bacteremia among COVID-19 patients were Escherichia coli (16.7\%), 171 Staphylococcus aureus (13.3\%), Klebsiella pneumoniae (10.0\%), and Enterobacter cloacae complex

$172(8.3 \%)$ (Supplemental Table 3). None of these pathogens were overrepresented among COVID-19 173 patients compared to the other groups. Incubation Period: Among the subset of 1859 positive blood cultures for which incubation period could be reliably

178 assessed, the vast majority (88.2\%) signaled positive within 1-2 days of incubation, with an additional

$1797.0 \%$ signaling positive on day 3 and 3.0\% signaling positive on day 4 (Figure 4 and Supplemental

180 Table 4). Only $1.8 \%$ of all blood cultures signaled positive on day 5, many of which yielded normal skin 181 microbiota (Supplemental Table 5). Among COVID-19 patients, $97.3 \%$ of positive cultures signaled 
medRxiv preprint doi: https://doi.org/10.1101/2020.05.05.20080044; this version posted May 6, 2020. The copyright holder for this preprint (which was not certified by peer review) is the author/funder, who has granted medRxiv a license to display the preprint in perpetuity. It is made available under a CC-BY-NC 4.0 International license.

182 positive within 3 days of incubation, with one culture positive on the $4^{\text {th }}$ day for Cutibacterium acnes and

183 one culture positive on the $5^{\text {th }}$ day for Candida albicans.

Discussion:

Beginning in March 2020, a surge of COVID-19 patients presenting to our network of hospitals in New York City, the current epicenter of the global COVID-19 pandemic $^{5}$, led to a dramatic increase in the utilization of blood cultures. In patients presenting with severe febrile illness, blood cultures are essential in ruling out bacterial infection and guiding appropriate antibiotic utilization. However, we

191 found a very low rate of bacteremia among patients diagnosed with COVID-19, implying a remarkably

192 low diagnostic yield of blood cultures for COVID-19 patients. When excluding likely contaminants,

193 COVID-19 patients had bacteremia rates that were less than one third of the baseline rate from 2019.

194 These data demonstrate that bloodstream infections appear to be very rare for COVID-19 patients, and 195 suggest that empiric antibiotics may not be useful in the absence of compelling evidence of an accompanying bacterial infection. Notably, we did not evaluate other bacterial infections such as bacterial

197 pneumonia, although other studies have shown low levels of procalcitonin among COVID-19 patients, 198 arguing that bacterial superinfection may be uncommon ${ }^{6-8}$.

As medical centers across the United States prepare for anticipated waves of COVID-19 patients, our data may be used to justify the judicious utilization of blood cultures to preserve the operational

201 capacity of diagnostic laboratories and to promote antimicrobial stewardship efforts to reduce

202 unnecessary antibiotic administration. Overordering of blood cultures during a COVID-19 surge within 203 our hospital network resulted in culture volumes that exceeded the capacity of our automated instruments, 204 requiring additional staff to manually process these cultures at a time when staffing and supplies were 205 already constrained. Our experience should serve as a caution to other medical centers that overordering 206 of blood cultures during patient surges can overwhelm laboratory capacity and may negatively impact the 207 quality of results for all patients. 
medRxiv preprint doi: https://doi.org/10.1101/2020.05.05.20080044; this version posted May 6, 2020. The copyright holder for this preprint (which was not certified by peer review) is the author/funder, who has granted medRxiv a license to display the preprint in perpetuity.

It is made available under a CC-BY-NC 4.0 International license.

As a harm-reduction measure, we decreased the incubation period of blood cultures from 5 days to 4 days after the study period concluded, which freed additional space to allow for timely processing of

210 incoming cultures. Our data demonstrate that this intervention likely had little to no adverse effect on

211 patient care, as all but one COVID-19 patients with positive cultures during the study period signaled

212 positive within 4 days, and only $1.8 \%$ of all positive cultures signaled positive on the $5^{\text {th }}$ day, many of

213 which were positive for normal skin microbiota. Previous studies have also shown that decreasing the

214 incubation of blood cultures to 4 days ${ }^{9}$ or even 3 days ${ }^{10,11}$ has minimal effect on positivity rates,

215 particularly for clinically significant bacteria.

216 To our knowledge, this study is the first to examine blood culture utilization among COVID-19

217 patients. The inclusion of over 88,000 patient cultures is a major strength of the study design, as is the

218 multicenter analysis from a wide geographic catchment area in New York City, which increases the

219 generalizability of our results. Limitations of the study include paucity of data on other bacterial co-

220 infections and lack of data on patient antibiotic utilization to demonstrate how blood culture utilization

221 impacted therapy.

222 In summary, we observed an overutilization of blood cultures during a surge of COVID-19

223 patients to our network of medical centers in New York City and found a very low rate of bloodstream

224 infections among COVID-19 patients. This overutilization was mitigated through a 4 day incubation with

225 likely minimal impact on patient care. Clear communication with ordering providers and hospital

226 leadership regarding the low yield of blood cultures is a necessary step to mitigate overordering and to

227 preserve laboratory functionality during these periods. Laboratories should also consider reducing the

228 incubation period of blood cultures from 5 days to 4 days to further increase their capacity.

230 Acknowledgments:

231 Potential conflicts of interest: J.J.C. has received research support from Roche Diagnostics. All other

232 authors have no conflicts. 
medRxiv preprint doi: https://doi.org/10.1101/2020.05.05.20080044; this version posted May 6, 2020. The copyright holder for this preprint (which was not certified by peer review) is the author/funder, who has granted medRxiv a license to display the preprint in perpetuity. It is made available under a CC-BY-NC 4.0 International license .

\section{References:}

235

236 1. Fomsgaard AS, Rosenstierne MW. An alternative workflow for molecular detection of SARS-CoV-2 - escape from the NA extraction kit-shortage, Copenhagen, Denmark, March 2020. Euro Surveill. 2020;25(14).

2392 2. Newton PN, Bond KC, signatories from c. COVID-19 and risks to the supply and quality of 240 tests, drugs, and vaccines. Lancet Glob Health. 2020.

241 3. Ranney ML, Griffeth V, Jha AK. Critical Supply Shortages - The Need for Ventilators and Personal Protective Equipment during the Covid-19 Pandemic. N Engl J Med. 2020.

243 4. Horan TC, Andrus M, Dudeck MA. CDC/NHSN surveillance definition of health careassociated infection and criteria for specific types of infections in the acute care setting. Am J Infect Control. 2008;36(5):309-332.

$2465 . \quad$ New York City Department of Health COVID-19 Data.

247 https://www1.nyc.gov/site/doh/covid/covid-19-data.page. Accessed April 21, 2020.

248 6. Guan WJ, Ni ZY, Hu Y, et al. Clinical Characteristics of Coronavirus Disease 2019 in China. $249 \quad$ N Engl J Med. 2020.

$2507 . \quad$ Lippi G, Plebani M. Procalcitonin in patients with severe coronavirus disease 2019 251 (COVID-19): A meta-analysis. Clin Chim Acta. 2020;505:190-191.

252 8. Lippi G, Plebani M. Laboratory abnormalities in patients with COVID-2019 infection. Clin 
9. Doern GV, Brueggemann AB, Dunne WM, Jenkins SG, Halstead DC, McLaughlin JC. Fourday incubation period for blood culture bottles processed with the Difco ESP blood culture system. J Clin Microbiol. 1997;35(5):1290-1292.

10. Bourbeau PP, Foltzer M. Routine incubation of BacT/ALERT FA and FN blood culture bottles for more than 3 days may not be necessary. J Clin Microbiol. 2005;43(5):25062509.

11. Bourbeau PP, Pohlman JK. Three days of incubation may be sufficient for routine blood cultures with BacT/Alert FAN blood culture bottles. J Clin Microbiol. 2001;39(6):20792082. 
$\underline{\text { Tables }}$

279 Table 1A - Distribution of blood culture results by SARS-CoV-2 status

\begin{tabular}{|c|c|c|c|c|c|c|c|}
\hline $\begin{array}{l}\text { SARS-CoV-2 } \\
\text { Status } \\
\text { Blood Culture } \\
\text { Result }\end{array}$ & $\begin{array}{c}\text { Jan-Feb, } \\
2019 \\
(\mathrm{~N}=29019)\end{array}$ & $\begin{array}{c}\text { Mar 1-15, } \\
2019 \\
(\mathrm{~N}=7601)\end{array}$ & $\begin{array}{c}\text { Mar 16-31, } \\
2019 \\
(\mathrm{~N}=7688)\end{array}$ & $\begin{array}{c}\text { Jan-Feb, } \\
2020 \\
(\mathrm{~N}=28593)\end{array}$ & $\begin{array}{c}\text { Mar 1-15, } \\
2020 \\
(\mathrm{~N}=6518)\end{array}$ & $\begin{array}{c}\text { Mar 16-31, } \\
2020 \\
(\mathrm{~N}=8784)\end{array}$ & $\begin{array}{c}\text { Total } \\
(\mathrm{N}=88203)\end{array}$ \\
\hline \multicolumn{8}{|l|}{ Not tested } \\
\hline Negative & $\begin{array}{c}27022 \\
(93.1 \%)\end{array}$ & $\begin{array}{c}7074 \\
(93.1 \%)\end{array}$ & $\begin{array}{c}7065 \\
(91.9 \%)\end{array}$ & $\begin{array}{c}26520 \\
(92.7 \%)\end{array}$ & $\begin{array}{c}5556 \\
(93.5 \%)\end{array}$ & $\begin{array}{c}1779 \\
(93.8 \%)\end{array}$ & $\begin{array}{c}75016 \\
(92.9 \%)\end{array}$ \\
\hline Positive & $\begin{array}{c}1997 \\
(6.9 \%)\end{array}$ & $\begin{array}{c}527 \\
(6.9 \%) \\
\end{array}$ & $\begin{array}{c}623 \\
(8.1 \%) \\
\end{array}$ & $\begin{array}{c}2073 \\
(7.3 \%) \\
\end{array}$ & $\begin{array}{c}386 \\
(6.5 \%)\end{array}$ & $\begin{array}{c}117 \\
(6.2 \%)\end{array}$ & $\begin{array}{c}5723 \\
(7.1 \%) \\
\end{array}$ \\
\hline \multicolumn{8}{|l|}{ Negative } \\
\hline Negative & 0 & 0 & 0 & 0 & $\begin{array}{c}431 \\
(93.7 \%)\end{array}$ & $\begin{array}{c}2317 \\
(91.7 \%)\end{array}$ & $\begin{array}{c}2748 \\
(92.0 \%)\end{array}$ \\
\hline Positive & 0 & 0 & 0 & 0 & $29(6.3 \%)$ & $\begin{array}{c}209 \\
(8.3 \%)\end{array}$ & $\begin{array}{c}238 \\
(8.0 \%)\end{array}$ \\
\hline \multicolumn{8}{|l|}{ Positive } \\
\hline Negative & 0 & 0 & 0 & 0 & $\begin{array}{c}110 \\
(94.8 \%)\end{array}$ & $\begin{array}{c}4198 \\
(96.2 \%)\end{array}$ & $\begin{array}{c}4308 \\
(96.2 \%)\end{array}$ \\
\hline Positive & 0 & 0 & 0 & 0 & $6(5.2 \%)$ & $\begin{array}{c}164 \\
(3.8 \%)\end{array}$ & $\begin{array}{c}170 \\
(3.8 \%)\end{array}$ \\
\hline
\end{tabular}

280

281 Table 1B - Distribution of blood culture results collected in March 2020 by SARS-CoV-2 status.

\begin{tabular}{|c|c|c|c|c|c|}
\hline $\begin{array}{l}\text { Blood } \\
\text { Culture }\end{array}$ & $\begin{array}{c}\text { Not tested } \\
(\mathrm{N}=7838)\end{array}$ & $\begin{array}{r}\text { Negative } \\
(\mathrm{N}=2986)\end{array}$ & $\begin{array}{c}\text { Positive } \\
(\mathrm{N}=4478)\end{array}$ & $\begin{array}{c}\text { Total } \\
(\mathrm{N}=15302)\end{array}$ & $p$ value \\
\hline
\end{tabular}

\begin{tabular}{|c|c|c|c|c|c|}
\hline \multirow[t]{3}{*}{$\begin{array}{l}\text { Mar 1-15, } \\
2020\end{array}$} & $\begin{array}{l}\text { Blood Culture } \\
\text { Result }\end{array}$ & & & & \\
\hline & Negative & $5556(93.5 \%)$ & $431(93.7 \%)$ & $110(94.8 \%)$ & $\begin{array}{c}6097 \\
(93.5 \%)\end{array}$ \\
\hline & Positive & $386(6.5 \%)$ & $29(6.3 \%)$ & $6(5.2 \%)$ & $421(6.5 \%)$ \\
\hline
\end{tabular}

Mar 16-31, Blood Culture

2020 Result

$0.840^{1}$

Negative $\quad 1779(93.8 \%) 2317(91.7 \%) 4198(96.2 \%) \quad 8294(94.4 \%)$

Positive $\quad 117(6.2 \%) \quad 209(8.3 \%) \quad 164(3.8 \%) \quad 490(5.6 \%)$ 
284 Table 2 - Most frequent microorganism groups isolated from blood cultures by SARS-CoV-2 285 status. Each species was counted once per patient, independently of how often it was isolated 286 from each patient, then grouped by the conventional categories.

\begin{tabular}{|c|c|c|c|c|c|}
\hline & $\begin{array}{l}\text { Not tested } \\
(\mathrm{N}=3928)\end{array}$ & $\begin{array}{l}\text { Negative } \\
(\mathrm{N}=153)\end{array}$ & $\begin{array}{l}\text { Positive } \\
(\mathrm{N}=159)\end{array}$ & $\begin{array}{c}\text { Total } \\
(\mathrm{N}=4240)\end{array}$ & $p$ value \\
\hline Microorganism & & & & & $<0.001^{1}$ \\
\hline Staphylococcus aureus & $344(8.8 \%)$ & $15(9.8 \%)$ & $8(5.0 \%)$ & $367(8.7 \%)$ & \\
\hline $\begin{array}{l}\text { Coagulase-negative } \\
\text { Staphylococcus }\end{array}$ & $1169(29.8 \%)$ & $49(32.0 \%)$ & $95(59.7 \%)$ & $1313(31.0 \%)$ & \\
\hline Other Gram-positive cocci & $702(17.9 \%)$ & $25(16.3 \%)$ & $21(13.2 \%)$ & $748(17.6 \%)$ & \\
\hline Gram-negative rods & $1187(30.2 \%)$ & $42(27.5 \%)$ & $16(10.1 \%)$ & $1245(29.4 \%)$ & \\
\hline Gram-positive rods & $236(6.0 \%)$ & $5(3.3 \%)$ & $15(9.4 \%)$ & $256(6.0 \%)$ & \\
\hline Gram-negative cocci & $6(0.2 \%)$ & $0(0.0 \%)$ & $0(0.0 \%)$ & $6(0.1 \%)$ & \\
\hline Anaerobes & $171(4.4 \%)$ & $10(6.5 \%)$ & $2(1.3 \%)$ & $183(4.3 \%)$ & \\
\hline Yeast & $113(2.9 \%)$ & $7(4.6 \%)$ & $2(1.3 \%)$ & $122(2.9 \%)$ & \\
\hline
\end{tabular}


medRxiv preprint doi: https://doi.org/10.1101/2020.05.05.20080044; this version posted May 6, 2020. The copyright holder for this preprint (which was not certified by peer review) is the author/funder, who has granted medRxiv a license to display the preprint in perpetuity. It is made available under a CC-BY-NC 4.0 International license .

288 Table 3 - Distribution of blood culture results by date and SARS-CoV-2 Status. Organisms were 289 labeled as likely contaminants if they were isolated only once per patient and belong to the 290 groups generally defined as skin contaminants

\begin{tabular}{lccccc}
\hline Blood & Not tested & Negative & Positive & Total & \\
Culture & $(\mathrm{N}=80739)$ & $(\mathrm{N}=2986)$ & $(\mathrm{N}=4478)$ & $(\mathrm{N}=88203)$ & p value \\
Date & & & &
\end{tabular}

\begin{tabular}{|c|c|c|c|c|c|c|}
\hline \multirow{4}{*}{$\begin{array}{l}\text { Jan-Feb } \\
2019\end{array}$} & \multicolumn{6}{|l|}{ BC Result } \\
\hline & Negative & $27022(93.1 \%)$ & 0 & 0 & $27022(93.1 \%)$ & \\
\hline & Likely Contaminant & $636(2.2 \%)$ & 0 & 0 & $636(2.2 \%)$ & \\
\hline & Positive & $1361(4.7 \%)$ & 0 & 0 & $1361(4.7 \%)$ & \\
\hline \multirow{4}{*}{$\begin{array}{l}\text { Mar } \\
1-15 \\
2019\end{array}$} & BC Result & & & & & \\
\hline & Negative & $7074(93.1 \%)$ & 0 & 0 & $7074(93.1 \%)$ & \\
\hline & Likely Contaminant & $154(2.0 \%)$ & 0 & 0 & $154(2.0 \%)$ & \\
\hline & Positive & $373(4.9 \%)$ & 0 & 0 & $373(4.9 \%)$ & \\
\hline \multirow{4}{*}{$\begin{array}{l}\text { Mar } \\
16-31 \\
2019\end{array}$} & BC Result & & & & & \\
\hline & Negative & 7065 (91.9\%) & 0 & 0 & 7065 (91.9\%) & \\
\hline & Likely Contaminant & $186(2.4 \%)$ & 0 & 0 & $186(2.4 \%)$ & \\
\hline & Positive & $437(5.7 \%)$ & 0 & 0 & $437(5.7 \%)$ & \\
\hline \multirow{4}{*}{$\begin{array}{l}\text { Jan-Feb } \\
2020\end{array}$} & BC Result & & & & & \\
\hline & Negative & $26520(92.7 \%)$ & 0 & 0 & $26520(92.7 \%)$ & \\
\hline & Likely Contaminant & $624(2.2 \%)$ & 0 & 0 & $624(2.2 \%)$ & \\
\hline & Positive & $1449(5.1 \%)$ & 0 & 0 & 1449 (5.1\%) & \\
\hline \multirow{4}{*}{$\begin{array}{l}\text { Mar } \\
1-15 \\
2020\end{array}$} & BC Result & & & & & $0.431^{1}$ \\
\hline & Negative & $5556(93.5 \%)$ & $431(93.7 \%)$ & $110(94.8 \%)$ & 6097 (93.5\%) & \\
\hline & Likely Contaminant & $128(2.2 \%)$ & $7(1.5 \%)$ & $4(3.4 \%)$ & $139(2.1 \%)$ & \\
\hline & Positive & $258(4.3 \%)$ & $22(4.8 \%)$ & $2(1.7 \%)$ & $282(4.3 \%)$ & \\
\hline \multirow{4}{*}{$\begin{array}{l}\text { Mar } \\
16-31 \\
2020\end{array}$} & BC Result & & & & & $<0.001^{1}$ \\
\hline & Negative & 1779 (93.8\%) & $2317(91.7 \%)$ & $4198(96.2 \%)$ & 8294 (94.4\%) & \\
\hline & Likely Contaminant & $31(1.6 \%)$ & $59(2.3 \%)$ & $96(2.2 \%)$ & $186(2.1 \%)$ & \\
\hline & Positive & $86(4.5 \%)$ & $150(5.9 \%)$ & $68(1.6 \%)$ & 304 (3.5\%) & \\
\hline
\end{tabular}


medRxiv preprint doi: https://doi.org/10.1101/2020.05.05.20080044; this version posted May 6, 2020. The copyright holder for this preprint (which was not certified by peer review) is the author/funder, who has granted medRxiv a license to display the preprint in perpetuity.

It is made available under a CC-BY-NC 4.0 International license .

\section{Figure Legends:}

294 Figure 1: Blood culture ordering volume by day in 2019 and 2020. Total blood cultures are shown in 295 purple and are broken down by SARS-CoV-2 status of "Positive" in blue, "Negative" in red, and "Not 296 tested" in green.

298 Figure 2: Rate of blood culture positivity by day in 2019 and 2020. The percentage of positive blood 299 cultures is shown in red and the total number of negative blood cultures is shown in blue.

301 Figure 3: Frequency of microorganisms identified from positive blood cultures stratified by SARS-CoV-2

302 status. Each microorganism was counted once per patient and grouped by the categories specified in the

303 figure legends. A. All microorganisms isolated were counted. B. Likely skin contaminant were excluded.

$304 * * *$ Pearson's chi-square p-value $<0.001$.

305

306 Figure 4: Time to positivity of positive blood cultures stratified by SARS-CoV-2 status. Time to

307 positivity was calculated from the time of collection to the first positive signal as recorded by the gram

308 stain date/time. The scaled density distribution of the time to positivity is shown as color-filled density

309 plots and the cumulative distribution of positivity over time is represented by solid lines. 
Figure 1 - Blood Culture Volumes

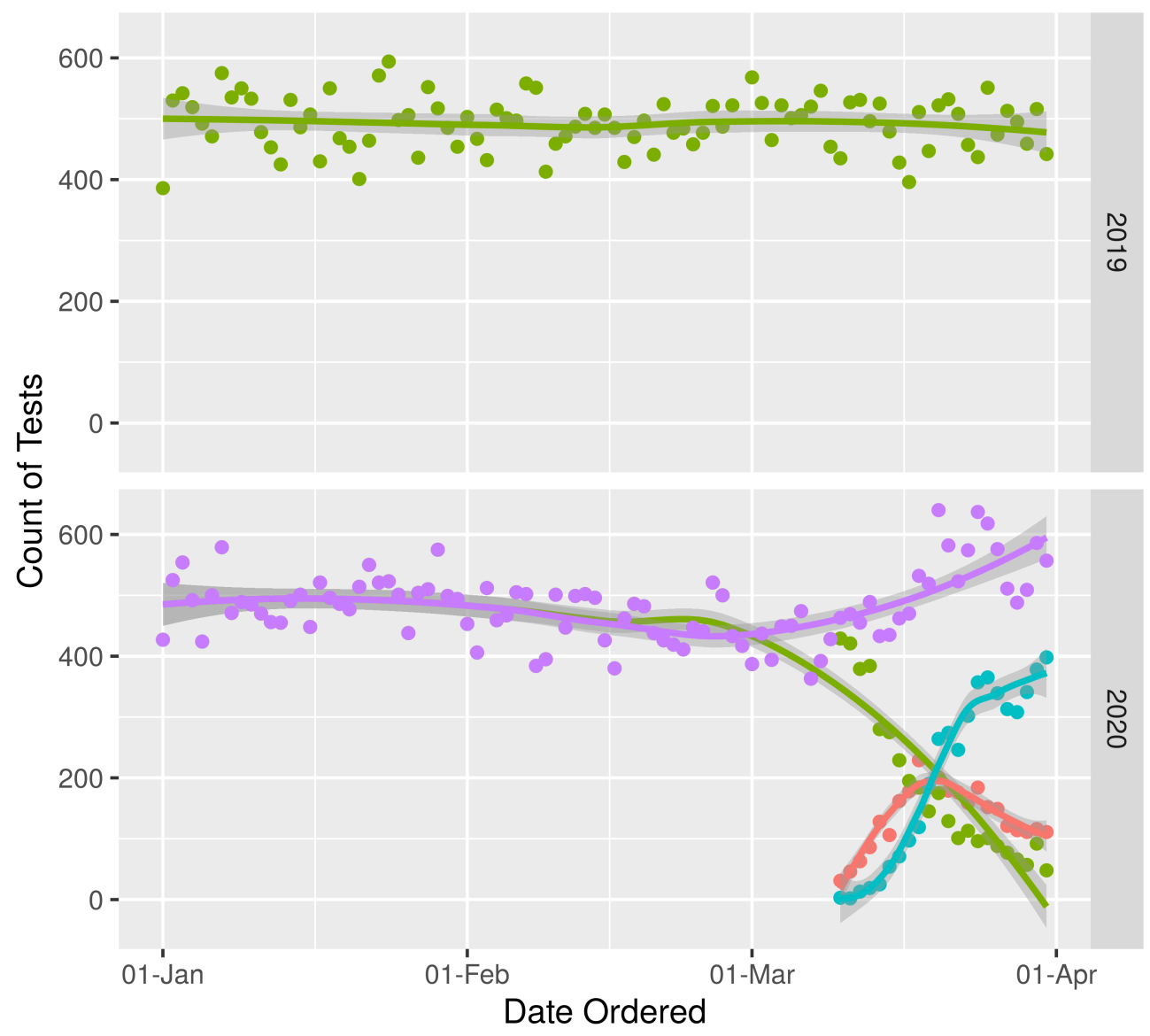

SARS-CoV-2 Status

Negative

Not tested

Positive

Total

Date Ordered 
Figure 2 - \% Positive Blood Cultures (in red) and Number of Negative Blood Cultures (in blue)

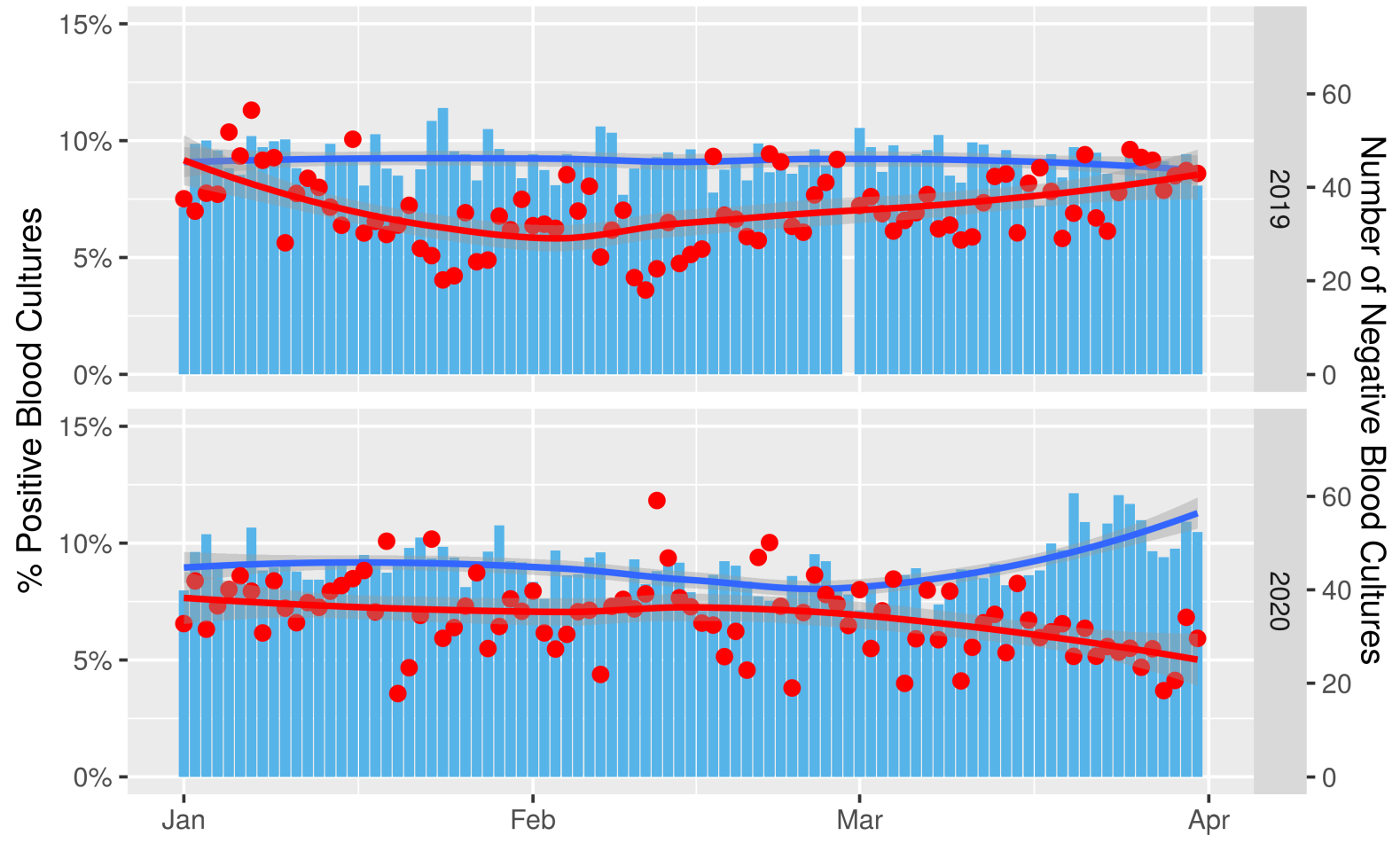


Figure 3-A. All positive cultures per patient

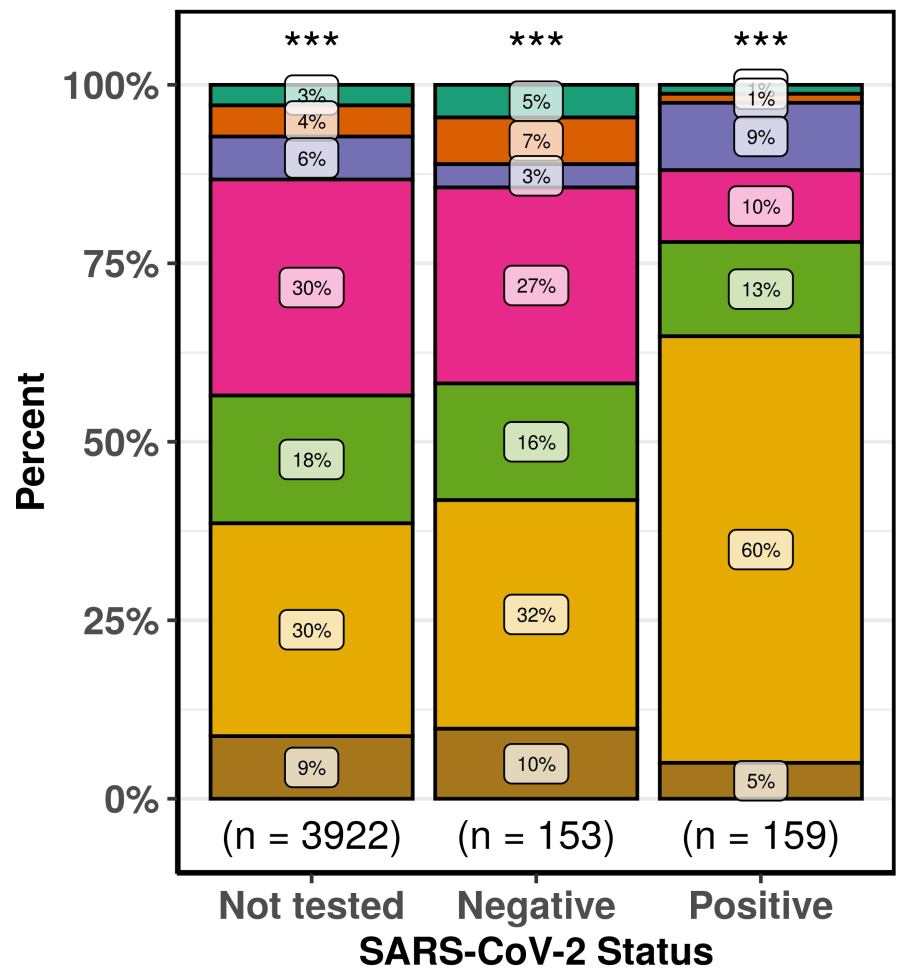

Figure 3-B. Positive cultures per patient after excluding likely contaminants

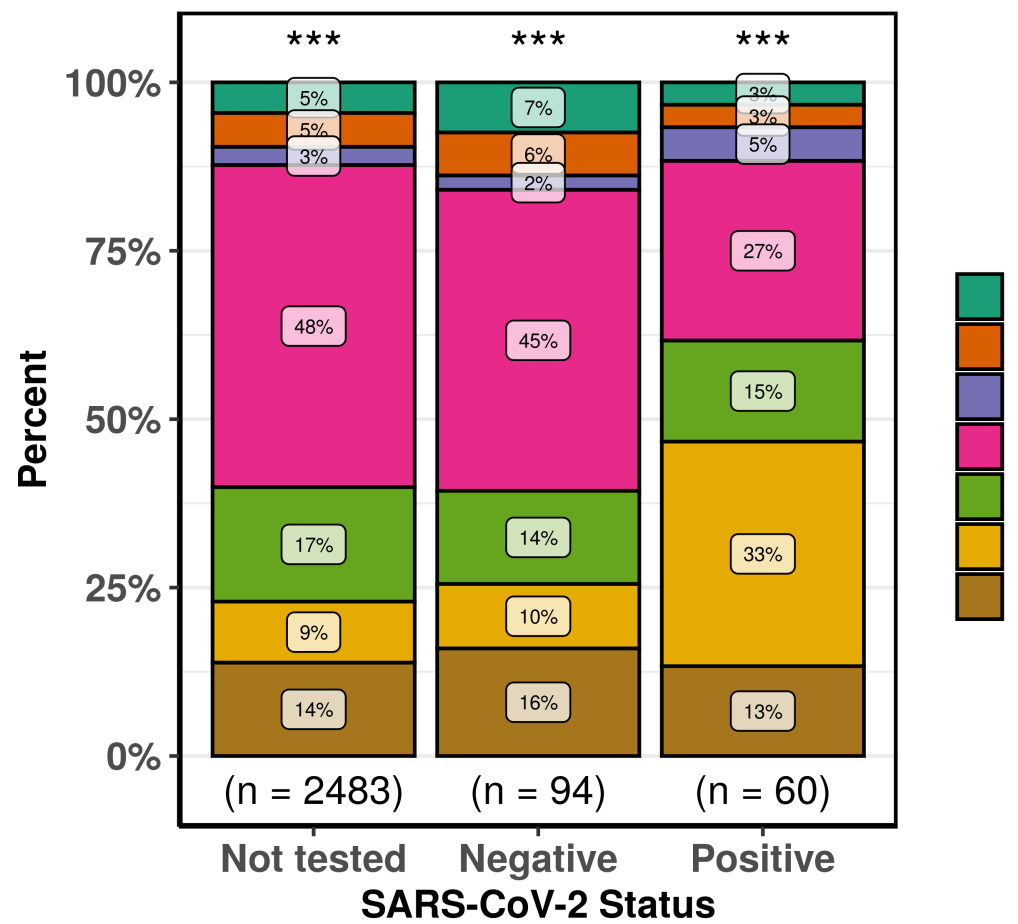

Microorganism class

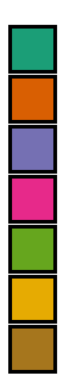

Yeast

Anaerobes

Gram-positive rods

Gram-negative rods

Other Gram-positive cocci

Coagulase-negative Staphylococcus

Staphylococcus aureus

\section{Microorganism class}

Yeast

Anaerobes

Gram-positive rods

Gram-negative rods

Other Gram-positive cocci

Coagulase-negative Staphylococcus

Staphylococcus aureus 
